\title{
DETERMINATION OF THE MINERAL AND VITAMIN COMPOSITIONS OF JACKFRUIT JUICE EXTRACT AND ITS EFFECT ON BROILER CHICKENS PERFORMANCE
}

\author{
O. O. EFFIONG AND B. J. HARRY \\ (Received 11 January 2019; Revision Accepted 11 February 2019)
}

\begin{abstract}
This study evaluated the mineral and vitamin compositions of jackfruit juice extract and its effect on broiler chicks' performance. Bunches of jackfruits were harvested, juice extracted and fortified with formic acid. Five (5) levels of the jackfruit juice extract supplements $(200,400 \mathrm{~g}, 600 \mathrm{~g}, 800 \mathrm{~g}$ and $1000 \mathrm{~g})$ were constituted, by absorbing the formic acid fortified fruit juice extract in corn starch. The samples were labelled, air dried in a dark room, packed in polyethylene bags and stored in a refrigerator at $2^{\circ} \mathrm{C}$, prior to the determination of the mineral and vitamin compositions. Broiler starter and finisher feeds were formulated and replicated in seven (7) parts. Conventional vitamin/mineral premix was added to the first part of the feed while the second to the seventh part of feeds were supplemented with each of the jackfruit juice extract /corn starch preparation. One hundred and forty seven day-old broiler chicks were weighed and distributed into the seven (7) groups and each group assigned to one of the seven diets in a complete randomized design and fed the starter diet (0-28 days)and the finisher diet (29-56 days). Data generated were analysed using the general linear models procedure of SPSS options, Version 18.00 (SPSS Inc., 2010). The results revealed that potassium $617.5 \mathrm{mg}$ ) was the most abundant mineral in the jackfruit juice extract while manganese, zinc, iron, selenium and sodium were the most limiting minerals. Vitamins $A$ and $C$, thiamine, riboflavin and niacin were the prominent vitamins in jack fruit juice. There was no treatment effect $(P>0.05)$ on the average daily feed intake, weight gain, feed conversion ratio and the carcass characteristic of the chickens at the starter and finisher phase. It was concluded that jackfruit juice extract supplement could be used to replace conventional vitamins/mineral premix in broiler diets. It was recommended that jackfruit juice extract supplement in broilers' diet should not exceed $400 \mathrm{~g}$ at starter phase and $200 \mathrm{~g} / 1 \mathrm{~kg}$ corn starch mixtures.
\end{abstract}

KEY WORDS: Minerals, vitamins, jackfruit extract, supplements, formic acid.

\section{INTRODUCTION}

Broiler chickens remain one of the fastest source of readily available animal protein for human consumption because of its rapid growth, under good nutrition and management (Oyewole et al., 2013). According to Swami et al. (2012), an adequate supply of vitamins and minerals is key for good poultry nutrition, strengthening the bird's body defense against harmful pathogens. Vitamins and minerals supplied by feedstuffs (fish meal, soybean and maize) are inadequate in meeting poultry requirement, therefore, dietary provision with synthetic vitamins and minerals premix is essential.

The definitive goal of poultry producers is to maximize production and to achieve a satisfactory economic return; therefore all nutrients requirements must be met particularly for minerals and vitamins. While the NRC (1994) gives smallest levels of minerals and vitamins that are necessary for optimum productivity, feed manufacturers use much higher concentrations to avoid deficiencies. According to Inal et al. (2001) feed manufacturers use 2-10 times of vitamins/minerals premix than those specified by the NRC. The cost of the premix supplementation may contribute up to $2-3 \%$ of the total cost of the feed, however augmenting the feed with higher levels of minerals and vitamins could lead to nutrient-minerals interaction. Several researches had been conducted to reduce or remove minerals, vitamins or both at different stages of production. Nilpour et al. (1994), stated that reduction of minerals and vitamins premix up to $50 \%$ had no adverse effects on broilers performance, while others documented that removing minerals and vitamins premix from broilers diet during the last two weeks of the finisher period (weeks 4 and 5) reduced the body weight gain(BWG) (Christmas et al., 1995). In the same way, Patel et al. (1997) reported that withdrawing vitamins/minerals premix from broiler chickens feed between 7-42 days decreased BWG in three different broiler strains.

Vitamins and minerals used in premix preparations in Nigeria are usually imported, more so the current high exchange rate has made it difficult for feed concentrates importers to trade on large volumes. Oyewole et al. (2013)opined that one of the ways of solving the problem is by preparing vitamins/minerals premix from locally available materials. It is therefore imperative for

O. O. Effiong, Department of Animal Science University of Calabar- Nigeria

B. J. Harry, Department of Animal Science Institute of Agricultural Research and Training, Moore Plantation, Ibadan 
the animal nutritionist to explore locally available fruits as vitamins as alternative vitamin/mineral premix. The fruit of economic importance in this regard is jackfruit juice extract, which according to Swami et al. (2012) is rich in B-complex group of vitamins, vitamin A and C. It is also known to be a good source of minerals including potassium, magnesium, manganese and iron as well as niacin (vitamin $B_{3}$ ) which is necessary for energy metabolism, nerve function, and the synthesis of certain hormones. A portion of $100 \mathrm{~g}$ of jackfruit pulp provides 4 mg niacin (Soobrattee et al., 2005).

\section{OBJECTIVES OF THE STUDY}

The objectives of this study were to determine the mineral and vitamin concentrations of jackfruit juice extract and to evaluate the effect of jackfruit juice extract supplement on the growth performance and carcass characteristics of broiler chickens

\section{MATERIALS AND METHOD Study location}

The mineral and vitamin analyses were carried out at the Animal Care Laboratory, Lagos, while the feeding trial was conducted at the Poultry Unit of Teaching and Research Farm, Department of Animal Science, University of Calabar, Calabar.

\section{COLLECTION AND PREPARATION OF TEST MATERIALS}

Bunches of jackfruit were harvested from home garden at Unical Satellite Town, Calabar, Cross River State. They were split open into two, using a sharp knife and the pulp separated from the seeds. The juice was extracted from the jackfruit pulp using fruit juice extractor, $10 \mathrm{mls}$ of concentrated formic acid added as an anti-oxidant and stored in a bottle in a refrigerator.

\section{PREPARATION OF THE JACKFRUIT JUICE EXTRACT SUPPLEMENTS}

Five (5) levels of the jackfruit vitamins/minerals supplements were constituted by weighing out $200 \mathrm{~g}, 400 \mathrm{~g}, 600 \mathrm{~g}, 800 \mathrm{~g}$ and $1000 \mathrm{~g}$ of the formic acid fortified jackfruit extract using digital scale and absorbed in $1 \mathrm{~kg}$ of corn starch, respectively. The samples were properly labelled, air dried in a dark corner of the laboratory, packed in polyethylene bags and stored in a refrigerator at $2^{\circ} \mathrm{C}$.

\section{DETERMINATION OF THE MINERAL AND VITAMIN COMPOSITIONS OF THE JACKFRUIT JUICE EXTRACT}

The minerals and vitamins composition of jackfruit juice extract were carried out after sample digestion using $24 \mathrm{~cm}^{3}$ mixtures of concentrated trioxonitrate $\mathrm{V}$ acid $\left(\mathrm{HNO}_{3}\right)$, concentrated tetraoxosulphate $\mathrm{VI}$ acid $\left(\mathrm{H}_{2} \mathrm{SO}_{4}\right)$ and $60 \%$ trioxochlorate $\mathrm{V}$ acid $\left(\mathrm{HClO}_{3}\right)(9: 2: 1 \mathrm{v} / \mathrm{v})$. Standard methods of AOAC (1990) was used for the elemental analysis; sodium and potassium were analysed using a flame photometer, while calcium, copper, iron, magnesium and manganese were analysed using an atomic absorption spectrophotometer (AAS), type photomultiplier tube, (PMT), and phosphorus content was determined calorimetrically with a spectrophotometer.

\section{EXPERIMENTAL DIETS}

Broiler starter and finisher diets were formulated (Table 1) to supply $23 \%$ and $19.5 \%$ of crude protein and 2850 $\mathrm{Kcal} / \mathrm{kg}$ and $2950 \mathrm{Kcal} / \mathrm{kg}$ of metabolisable energy, respectively. The diets were replicated in seven (7) parts at each phase and supplemented as follows:

Diet 1 - Contain conventional vitamin/mineral premix

Diet 2 - No vitamin/mineral premix

Diet $3-200 \mathrm{~g} / \mathrm{kg}$ of jackfruit juice extract/corn starch mixture

Diet $4-400 \mathrm{~g} / \mathrm{kg}$ of jackfruit juice extract/corn starch mixture

Diet $5-600 \mathrm{~g} / \mathrm{kg}$ of jackfruit juice extract/corn starch mixture

Diet $6-800 \mathrm{~g} / \mathrm{kg}$ of jackfruit juice extract/corn starch mixture

Diet $7-1000 \mathrm{~g} / \mathrm{kg}$ of jackfruit juice extract/corn starch mixture

\section{EXPERIMENTAL BIRDS AND MANAGEMENT}

One hundred and forty seven day-old broiler chicks was purchased from Agrictech Hatchery Company, Ibadan through a reputable supplier in Calabar for the study. The chicks were divided into seven (7) groups of twenty one chicks each. Each group was further sub-divided into three replicates of seven birds per replicate. Each group was assigned randomly to one of the seven diets and fed for 28 days of the starter phase and 28 days of the finisher phase.

\section{DATA COLLECTION}

Data monitored were the average daily feed intake and the average weekly weight gain. The feed conversion ratio was computed on weekly basis from the average weekly feed intake and the average weekly weight gain At the end of the finisher phase, six birds per treatment (three per replicate) were selected for carcass evaluation. The birds were starved overnight with ample supply of drinking water. Each bird was weighed separately the following morning and slaughtered by severing the jugular and carotid veins. Thereafter they were allowed to bleed and followed by scalding at about $80^{\circ} \mathrm{C}$. Plucking of feathers was carried out manually and carefully to avoid tearing the skin. The weight of each bird was taken after bleeding and plucking. The plucked carcasses were dissected and eviscerated by removing the internal organs, the head and the shanks. The head, shanks and the internal organs (intestine, crop, proventriculus, gizzard, kidney, liver, heart and lungs) were separately weighed using a sensitive electronic balance and likewise the eviscerated carcasses. The eviscerated carcass was carefully cut into major parts like thighs, drumsticks, breast, and back and weighed separately. The respective weights of different parts of the chickens were recorded and expressed as a percentage of live weight of the birds.

Data generated were analysed using the general linear models procedure of SPSS options, Version 18.00 (SPSS Inc., 2010). 


\section{RESULTS AND DISCUSSION}

\section{VITAMIN COMPOSITION OF JACK FRUIT JUICE EXTRACT}

The vitamin compositions of jackfruit juice extract are presented in Table 2.

The result showed that jackfruit juice contains $146 \mathrm{IU}$ of vitamin $\mathrm{A}, 18.35 \mathrm{mg}$ of vitamin $\mathrm{C}, 0.138 \mathrm{mg}$ of thiamine, $0.073 \mathrm{mg}$ of riboflavin and $12.75 \mathrm{mg}$ of Niacin. The vitamin A composition of jackfruit meal in this study was slightly higher than 110 IU reported by Boning (2006) but lower than $182 \mathrm{IU}$ in the reported by Love and Paul (2011). Lansky (2007) however recorded vitamin A concentration of $496 \mathrm{IU}$ in orange fruit juice.

The concentration of vitamin $C$ in jackfruit juice obtained in this study was higher than $13.7 \mathrm{mg}$ reported by Boning (2006) for jackfruit juice but lower than $23 \mathrm{mg}$ reported by Love and Paul (2011) for jackfruit juice extract. The difference may be attributed to the methods of extraction employed, which may have resulted in the loss of some vitamins. The vitamin $\mathrm{C}$ concentrations in mango and orange with value corresponding to $27 \mathrm{mg}$ and $124.0 \mathrm{mg}$, reported by Lansky (2007) and Andres (2013) were higher than the value obtained from this study.

The thiamine concentration reported by Boning (2006) for orange juice with value corresponding to $0.105 \mathrm{mg}$ was lower than the value obtained from this study. Love and Paul (2011) and Andres (2013) reported 0.17mg and $0.223 \mathrm{mg}$ as thiamine component of mango and orange, which were higher than the value obtained in this research.

Riboflavin concentration obtained from this study was lower than the $0.091 \mathrm{mg}$ in the report of Love and Paul (2011) but higher than the $0.055 \mathrm{mg}$ reported by Boning (2006), but comparable to $0.074 \mathrm{mg}$ reported for orange by Andres (2013).

The niacin concentration obtained in this study was higher than the $1.5 \mathrm{mg}$ reported by Love and Paul (2011) and $0.992 \mathrm{mg}$ reported by Andres (2013) for orange but lower than $24 \mathrm{mg}$ reported by Boning (2006). The variations observed between the vitamins content of jackfruit juice and those of other jackfruits reported by other researchers may be attributed to the method of analysis, age at which the crop was harvested as well as method of processing.

\section{MINERAL COMPOSITION OF JACK FRUIT EXTRACT}

Potassium was the most abundant mineral in the jackfruit juice extract, with the value corresponding to $617.5 \mathrm{mg}$. The concentrations of magnesium $(38.5 \mathrm{mg})$, phosphorous $(37.5 \mathrm{mg})$ and calcium $(33.5 \mathrm{mg})$ were observed to be similar to each other, while manganese, zinc, iron, selenium and sodium concentrations with values corresponding to $0.134 \mathrm{mg}, 0.1675 \mathrm{mg}, 0.44 \mathrm{mg}$, $0.795 \mathrm{mg}$ and $2.65 \mathrm{mg}$ were the most limiting minerals in the jackfruit juice extract in the ascending order. The composition of calcium, iron, phosphorous, magnesium, potassium with values corresponding to $37.0 \mathrm{mg}, 1.1 \mathrm{mg}$, $41.0,27.0 \mathrm{mg}, 407 \mathrm{mg}, 41.0 \mathrm{mg}$, respectively, reported by Azad (2000) for jackfruit juice extract were comparable to the result of this experiment.

The mineral composition of jackfruit juice extract from this experiment was also comparable to the values reported by USDA (2007). The author reported $34 \mathrm{mg}$, $0.60 \mathrm{mg}, 37 \mathrm{mg}, 36 \mathrm{mg}, 303 \mathrm{mg}, 3 \mathrm{mg}, 0.42 \mathrm{mg}, 0.6 \mathrm{mg}$ and
$0.197 \mathrm{mg}$, respectively as the composition of calcium, iron, magnesium, phosphorous, potassium, sodium, zinc, selenium and manganese in jackfruit juice. Gumsena et al. (1996) noted calcium (40mg), iron (0.38mg), phosphorous (35mg), magnesium (48mg), potassium $(739 \mathrm{mg})$, sodium $(3.3 \mathrm{mg})$, zinc $(0.215 \mathrm{mg})$, selenium $(0.99 \mathrm{mg})$ and manganese $(0.071 \mathrm{mg})$ as constituents of jackfruit juice.

The result of the mineral composition of jackfruit juice extract in this experiment was also similar to those of orange juice (USDA, 2007), paw-paw (Azad, 2001) and mango juice (USDA 2007).

\section{GROWTH PERFORMANCE OF BROILER CHICKS FED DIETS CONTAINING JACKFRUIT JUICE EXTRACT SUPPLEMENTS STARTER PHASE.}

The results of growth performance of starter broilers fed diet containing jackfruit juice extract as vitamin/mineral supplement is presented in Table 4.

The result showed that the average daily weight gain ranged from $13.13 \mathrm{~g}$ among broiler chicks fed diet 7 to $16.69 \mathrm{~g}$ for those ondiets 1 and 4 , respectively.

The average daily feed intake ranged from $34.28 \mathrm{~g}$ among broiler chicks fed diet 7 to $48.56 \mathrm{~g}$ for the groups fed diet 1 . Dietary supplementation with jackfruit juice extract preparations did not $(P>0.05)$ influence the average daily feed intake of the chicks adversely.

The values for feed conversion ratio ranged from 2.61 for broiler chicks fed diet 7 to 3.14 for starter broiler chicks on diet 2 . The treatment did not significantly ( $P>0.05)$ influenced the feed conversion ratio of the chicks. Comparatively, it was observed that broiler chicks fed diets 3 and 4 had better average daily weight gain and feed conversion ratio to those on diet 2 .

\section{GROWTH PERFORMANCE OF FINISHER BROILERS FED JACKFRUIT JUICE EXTRACT SUPPLEMENTED DIETS.}

Data for the growth performance of finisher broilers fed diet containing jackfruit juice extract as vitamin/mineral supplement is presented in Table 4.

It was observed that the average daily feed intake ranged from $61.37 \mathrm{~g}$ among finisher broilers fed diet 7 to $98.30 \mathrm{~g}$ for finisher broilers fed diet 3 . Variation in the average daily feed intake between finisher broiler chicks fed diet 2 and those fed jackfruit juice extract supplements diets were not significant $(P>0.05)$.

The average daily weight gain ranged from $19.26 \mathrm{~g}$ for finisher broilers fed diet $8 \mathrm{to} 30.14 \mathrm{~g}$ for those on diet 3 .

Feed conversion ratio values were $3.03,3.51,3.26$, $3.72,3.55,3.19$ and 3.02 for finisher broiler birds fed diets $1,2,3,4,5,6$ and 7 , respectively. Values of feed conversion ratio were statistically $(P>0.05)$ similar among treatment groups.

Absence of anomalies (muscle weakness, paralysis and respiratory distress), implies that adequate minerals and vitamins were supplied in sufficient quantity to meet chicks' requirement during brooding. Similarities in average daily feed intake, weight gain and feed conversion ratio among birds fed control diet and those on diets containing jackfruit juice extract goes further to support this fact. Calcium and phosphorus are major components of the skeletal system: calcium plays a key role in organic processes, such as heart function, muscle contraction, coagulation and electrolyte equilibrium of the blood while phosphorus is involved in 
energy metabolism. Studies have proven that, diet rich in potassium aids in normal $\mathrm{pH}$ balance. According to de Blas and Wiseman (2010), an excess of calcium $(>15 \mathrm{~g} / \mathrm{kg})$ increases the calcification of soft tissues and can reduce the absorption of phosphorus and zinc, which may lead to deficiencies in those minerals while excess of dietary phosphorus $(>9 \mathrm{~g} / \mathrm{kg}$ ) may reduce feed intake. According to Bolaji (2005) sodium, potassium and chloride play key role in the acid-base regulation of the blood and other body fluids with potassium being a cofactor for several enzymes. Deficiency symptoms include muscle weakness, paralysis and respiratory distress. Copper is involved in iron and energy metabolism, as well as Collagen and hair formation. Copper deficiencies result in anaemia, retarded growth, bone abnormalities and greying of black hair. Copper is commonly used across the world as a growth promoter in swine and poultry (de Blas and Wiseman, 2010.)

From the result of this study, it was also observed that dietary increase in jackfruit juice extract at level above $200 \mathrm{~g}$ jackfruit juice extract/1 $\mathrm{kg}$ of corn starch did not improve the average daily weight gain of birds.

\section{CARCASS AND INTERNAL ORGANS CHARACTERISTICS OF BROILER CHICKENS FED JACKFRUIT JUICE EXTRACT SUPPLEMENTED DIETS.}

Data for the carcass and internal organs characteristics of broiler chickens fed diets with jackfruit juice extract are presented in Table 5.

The result showed that live weight, dressed weight, dressing percentage and relative weights of prime cuts and internal organs were not significantly $(P>0.05)$ influenced by dietary treatments, except for head whose value was influenced $(\mathrm{P}<0.05)$ significantly. It was observed that broiler chickens fed diet 4 recorded the highest value of $3.51 \%$ for the head while the least value, corresponding to $2.40 \%$ was recorded for birds fed diet with $400 \mathrm{~g}$ jackfruit juice extract $/ 1 \mathrm{~kg}$ corn starch. Similarities in the relative weights of carcass and internal organs are an indication that the minerals and vitamins in the jackfruit juice extract was sufficient to meet the nutrient requirement of the chickens.

\section{CONCLUSION}

From the result of this study, it was concluded that jackfruit juice extract supplement could be used to replace conventional vitamins/mineral premix in broiler chickens, diet without significant detrimental effects on growth performance and health status of the birds.

It was therefore recommended that the inclusion of jackfruit juice extract supplement in broilers' diet should not exceed $400 \mathrm{~g} / \mathrm{kg}$ of corn starch at starter phase and $200 \mathrm{~g} / 1 \mathrm{~kg}$ corn starch mixture at finisher phase.

\section{REFERENCES}

Azad, A. K., 2000. Genetic diversity of jackfruit in Bangladesh and development of propagation methods. PhD Thesis, University of Southampton, UK.

AOAC., 1990. Association of Official Analytical Chemists, Recommendations of medicine. 1:11.

Andres, G. C., 2013. Organization de la diversida genetic de los citricos (thesis). 79.
Bolaji, O. S., 2005. Annual welfare veterinary science. (Handbook). Ibadan: Evans Publishers.

Boning, C. R., 2006. Floridas best fruit plants; Native and exotic trees, shrubs and vines. Sarasota Florida: Pineaple press Inc. 107.

Christmas, R.B., R.H. Harmas and Sloan, D.R., 1995. The absence of vitamins and minerals and broilers performance. J. Applied Poult. Res., 4: 407-410.

De Blas, J. C. and Wiseman, J. (2010). Nutrition of poultry bird. $2^{\text {nd }}$. CABI Publishing; Wallingford, UK: 243-245.

Gunasena, H. P. M., Ariyadasa, K. P., Wikramasingh. A., Herath, H. M. W., Wikramasinghe, P. and Rajakaruna, S.B., 1996. Manual of jackfruit cultivation in Srilanka. Forest information service, forest department; 48.

Inal, F., Coskun B., Guisen, N. and Kurtoglu, V., 2001. The effects of withdrawal of vitamin and mineral supplement from layer diets on egg yields and trace mineral composition. Britain poultry sci. 42:77-80.

Lansky, E. P., Newman, R. A., 2007. Punica granatrim and its potential for prevention and treatment of inflammation and cancer. Ethnopharmacol. 109:177-206.

Love, K. and Paul, R. E., 2011. College of tropical agriculture and human resources. University of Hawail at Manoa

Nilipour, A. H., Fabrego, R., and Butcher, B. D., 1994. Determine the effect of withdrawing various levels of vitamin and minerals from the broiler finisher diets. Poult sci., 73:153-153.

NRC 1994. Nutrient requirements of poultry. Ninth revised edition, National Academy Press, Washington D.C

Oyewole, B. O., Olarenwaju, G. and Dafwang, L. L., 2013. Performance of broilers fed premix prepared from locally sourced materials. Standard. Res. J. Agric. Sci. 1:17-20.

Patel, K. P., M. H. Edwards, L. L. L and D.H. Baker., 1997. Removal of vitamins and trace minerals supplements from broiler finisher diets. $J$. Applied poult. Res., 6; 191-198.

Swami, B. S., Thakor, N. J, Haldankar, P. M., Kalse, S.B., 2012. Jackfruit and its many functional components as related to human health: a review. Food sci. and food safety. 11(6):1-11

Soobrattee, M.A., Neergheen, V.S., Luximon-Ramma A., Aruma, O.I. and Bahorun, T., 2005. Phenolics as potential antioxidant therapeutic agents; mechanism and action $\mathrm{J}$. of Mutation Res. 579:200-213. 
USDA 2007. Table of nutrient retention factors. Release (PDF) USDA.

SPSS Inc. Version 18.0.0 SPSS; Chicago. IL, USA: 2010
Waldroup, P. W., T.E. Bowen, H. L. Morrison, S. J., Hull and Tollett, 1968. The influence of EDTA on performance of chicks fed corn supplementation. Poult. Sci., 47: 956-960.

Table 1: Percentage composition of broiler chickens feed

\begin{tabular}{l|l|l}
\hline Ingredients & ${ }^{*}$ Starter & ${ }^{*}$ Finisher \\
\hline Yellow maize & 50 & 57.00 \\
Soybean meal & 34 & 24.00 \\
Fish meal & 3.0 & 2.00 \\
Palm kernel cake & 4.0 & 5.00 \\
Wheat offal & 5.0 & 8.00 \\
Di-calcium phosphate & 3.0 & 3.00 \\
Salt & 0.4 & 0.30 \\
Vitamin/mineral premix & 0.5 & 0.50 \\
Lysine & 0.2 & 0.10 \\
Methionine & 0.2 & 0.10 \\
\hline Total & & 100.00 \\
\hline Analysis & & \\
Crude protein (\%) & 22.00 & 19.50 \\
Metabolizable & 2853.04 & 2923.19 \\
energy(Kcal/kg) & & \\
Crude fibre (\%) & 3.22 & 3.98 \\
\hline
\end{tabular}

*Diet 1: containing conventional vitamin/mineral premix

Diet 2: containing no vitamin/mineral premix (negative control)

Diet 3: containing $200 \mathrm{~g}$ jackfruit juice extract $/ 1 \mathrm{~kg}$ of ash

Diet 4: containing $400 \mathrm{~g}$ jackfruit juice extract $1 \mathrm{~kg}$ of ash

Diet 5: containing $600 \mathrm{~g}$ jackfruit juice extract $/ 1 \mathrm{~kg}$ of ash

Diet 6: containing $800 \mathrm{~g}$ jackfruit juice extract $/ 1 \mathrm{~kg}$ of ash

Diet 7: containing $1000 \mathrm{~g}$ jackfruit juice extract $/ 1 \mathrm{~kg}$ of ash

\begin{tabular}{ll}
\hline & Table 2: Vitamins composition of jack fruit \\
\hline Vitamin & Composition \\
\hline Vitamin A & $1461 \mathrm{U}$ \\
Vitamin C & $18.35 \mathrm{mg}$ \\
Thiamine & $0.138 \mathrm{mg}$ \\
Riboflavin & $0.073 \mathrm{mg}$ \\
Niacin & $12.75 \mathrm{mg}$ \\
\hline
\end{tabular}

Table 3: Minerals composition of jack fruit

\begin{tabular}{ll}
\hline Minerals & Composition \\
\hline Calcium & $33.5 \mathrm{mg}$ \\
Iron & $0.44 \mathrm{mg}$ \\
Phosphorous & $38.5 \mathrm{mg}$ \\
Magnesium & $37.5 \mathrm{mg}$ \\
Potassium & $617.5 \mathrm{mg}$ \\
Sodium & $2.65 \mathrm{mg}$ \\
Zinc & $0.1675 \mathrm{mg}$ \\
Selenium & $0.795 \mathrm{mg}$ \\
Manganese & $0.134 \mathrm{mg}$ \\
\hline
\end{tabular}

Values are means of triplicate determination 
O. O. EFFIONG AND B. J. HARRY

Table 4: Growth performance of broiler chicks fed diets containing jackfruit juice extract supplements starter phase

\begin{tabular}{lllllllll}
\hline & & \multicolumn{7}{c}{ Treatments } \\
Parameters & Positive & Negative & $\mathbf{2 0 0} \mathbf{g}$ & $\mathbf{4 0 0} \mathbf{g}$ & $\mathbf{6 0 0} \mathbf{g}$ & $\mathbf{8 0 0} \mathbf{g}$ & $\mathbf{1 0 0 0} \mathbf{g}$ & $\mathbf{S E M}$ \\
\hline Initial weight & 52.50 & 52.50 & 52.50 & 52.50 & 52.50 & 52.50 & 52.50 & 0.00 \\
$\begin{array}{l}\text { Final weight } \\
\text { Total weight }\end{array}$ & 519.70 & 447.20 & 485.00 & 520.00 & 452.50 & 460.00 & 420.00 & 14.30 \\
gain & & 394.70 & 432.50 & 467.50 & 400.00 & 407.50 & 367.50 & 14.30 \\
$\begin{array}{l}\text { Daily weight gain } \\
\text { Daily feed intake }\end{array}$ & 16.69 & 14.10 & 15.45 & 16.69 & 14.29 & 14.55 & 13.13 & 0.51 \\
$\begin{array}{l}\text { Feed conversion } \\
\text { ratio }\end{array}$ & 2.91 & 43.78 & 43.48 & 46.77 & 43.16 & 48.46 & 34.28 & 1.85 \\
\hline
\end{tabular}

Positive: containing conventional vitamin/mineral premix

Negative: containing no vitamin/mineral premix (negative control)

$\mathrm{SEM}=$ Standard error of mean

Table 5: Growth performance of finisher broilers fed jackfruit juice extract supplemented diets

\begin{tabular}{lllllllll}
\hline & \multicolumn{7}{c}{ Treatments } \\
Parameters & Positive & Negative & $\mathbf{2 0 0} \mathbf{g}$ & $\mathbf{4 0 0} \mathbf{g}$ & $\mathbf{6 0 0} \mathbf{g}$ & $\mathbf{8 0 0} \mathbf{g}$ & $\mathbf{1 0 0 0} \mathbf{~ g}$ & $\mathbf{S E M}$ \\
\hline Initial weight & 519.70 & 519.75 & 519.81 & 519.96 & 519.72 & 519.68 & 519.93 & 0.00 \\
Final weight & 1339.30 & 1217.85 & 1364.00 & 1145.50 & 1085.80 & 1059.00 & 1116.14 & 144.59 \\
Total body weight & 819.10 & 698.10 & 844.19 & 625.54 & 566.08 & 539.32 & 596.21 & 144.59 \\
$\begin{array}{l}\text { Average daily weight } \\
\text { gain }\end{array}$ & 29.25 & 24.93 & 30.14 & 22.34 & 20.22 & 19.26 & 21.29 & 5.16 \\
$\begin{array}{l}\text { Average daily feed } \\
\text { intake }\end{array}$ & 88.59 & 87.47 & 88.30 & 80.11 & 67.94 & 61.37 & 64.39 & 18.65 \\
Feed conversion ratio & 3.03 & 3.51 & 2.92 & 3.59 & 3.36 & 3.19 & 3.02 & 0.35 \\
\hline
\end{tabular}

Positive: containing conventional vitamin/mineral premix

Negative: containing no vitamin/mineral premix (negative control)

SEM = Standard error of mean 
DETERMINATION OF THE MINERAL AND VITAMIN COMPOSITIONS OF JACKFRUIT JUICE

29

Table 6: Carcass and internal organs characteristics of broiler chickens fed jackfruit juice extract supplemented diets

\begin{tabular}{|c|c|c|c|c|c|c|c|c|}
\hline \multicolumn{9}{|c|}{ Treatment } \\
\hline Parameters & Positive & Negative & $200 \mathrm{~g}$ & $400 \mathrm{~g}$ & $600 \mathrm{~g}$ & $800 \mathrm{~g}$ & $1000 \mathrm{~g}$ & SEM \\
\hline Live weight & 1475.00 & 1200.00 & 1550.00 & 1275.00 & 1275.00 & 1125.00 & 1275.00 & 248.7 \\
\hline Dressed weight & 889.42 & 697.00 & 950.00 & 950.00 & 962.00 & 754.87 & 757.00 & 237.5 \\
\hline $\begin{array}{l}\text { Dressing } \\
\text { percentage }\end{array}$ & 60.3 & 58.6 & 60.5 & 75.4 & 76.4 & 67.1 & 59.4 & 13.57 \\
\hline \multicolumn{9}{|c|}{ Carcass characteristics (\% live weight) } \\
\hline Back & 13.25 & 12.66 & 13.50 & 16.04 & 17.80 & 16.14 & 12.22 & 2.15 \\
\hline Breast & 16.6 & 14.7 & 15.1 & 21.8 & 21.6 & 20.2 & 16.1 & 3.51 \\
\hline Drum stick & 9.43 & 9.48 & 9.30 & 11.25 & 12.9 & 12.65 & 9.41 & 1.74 \\
\hline Thigh & 9.51 & 9.36 & 9.84 & 11.95 & 13.45 & 13.55 & 9.21 & 1.99 \\
\hline Wings & 7.33 & 7.55 & 7.61 & 8.95 & 9.70 & 10.25 & 7.95 & 1.28 \\
\hline Neck & 4.10 & 4.45 & 4.67 & 5.08 & 6.87 & 5.40 & 4.20 & 0.79 \\
\hline Shank & 4.18 & 4.67 & 9.38 & 4.67 & 5.15 & 5.34 & 4.55 & 1.89 \\
\hline Head & $2.56^{\mathrm{ab}}$ & $3.00^{a b}$ & $2.40^{\mathrm{b}}$ & $2.86^{\mathrm{ab}}$ & $3.40^{\mathrm{ab}}$ & $3.51^{a}$ & $2.80^{\mathrm{ab}}$ & 0.28 \\
\hline \multicolumn{9}{|c|}{ Internal organs characteristics (\% live weight) } \\
\hline Liver & 3.00 & 3.26 & 3.34 & 4.90 & 2.76 & 3.76 & 2.90 & 0.62 \\
\hline Lungs & 0.55 & 0.44 & 0.57 & 0.65 & 0.53 & 0.49 & 0.50 & 0.11 \\
\hline Pancreas & 0.55 & 0.50 & 0.55 & 1.02 & 0.70 & 0.72 & 0.43 & 0.23 \\
\hline Proventriculus & 0.62 & 0.75 & 0.86 & 0.92 & 0.77 & 0.91 & 0.60 & 0.16 \\
\hline Gizzard & 3.80 & 4.17 & 4.87 & 4.96 & 4.47 & 4.49 & 4.35 & 1.11 \\
\hline Heart & 0.42 & 0.50 & 0.50 & 0.50 & 0.70 & 0.65 & 0.52 & 0.49 \\
\hline Abdominal fat & 1.24 & 1.12 & 1.12 & 1.27 & 1.30 & 1.65 & 1.04 & 0.47 \\
\hline
\end{tabular}

abc $=$ Means with different superscripts on the same row differ significantly $(P<0.05)$,

Positive: containing conventional vitamin/mineral premix

Negative: containing no vitamin/mineral premix (negative control)

SEM = Standard error of mean 